\title{
Rearranged and Unrearranged Angucyclinones from Indonesian Streptomyces spp.
}

\author{
Serge Fotso, Taifo Mahmud, T. Mark Zabriskie, Dwi Andreas Santosa, Sulastri, \\ Philip J. Proteau
}

Received: March 15, 2008 / Accepted: July 8, 2008

(C) Japan Antibiotics Research Association

\begin{abstract}
Two Indonesian Streptomyces strains, ICBB8309 and ICBB8415, were investigated for their ability to produce antibiotic compounds. In addition to the known antibiotics actiphenol, naramycin $B$, and sabaramycin, six new angucyclinones were identified. The isolation, structure elucidation and biological activities for the six new compounds are presented. The angucyclinones 7-deoxo-6-deoxy-7-hydroxy-8-O-methylrabelomycin, 1deoxo-1-hydroxy-8- $O$-methylrabelomycin, and the angucycline 7-deoxo-7-hydroxy-1- $O$ - $\alpha$-rhamnosyl-8- $O$ methyltetrangulol have common angular backbones, while angucyclinone $\mathrm{C}$, limamycin $\mathrm{A}$, and limamycin $\mathrm{B}$ appear to be rearranged angucyclinones.
\end{abstract}

Keywords Streptomyces metabolites, angucyclinone, polyketide, antibiotics, MTT assay

\section{Introduction}

In the course of screening for new antibiotics from Indonesian Black Water Ecosystem microorganisms [1], two Streptomyces isolates were found to produce a variety of related bioactive metabolites. The strain ICBB8309 was isolated from a peat soil sample collected from the Black Water river Sungai Kala, Garung Village, Pulang Pisau and
ICBB8415 was isolated from a soil sample from the Black Water river Pangkoh Lima, Malibu Village, Pulang Pisau. The $\mathrm{pH}$ of the water in this ecosystem is 5.0. Further investigation of the extracts from these strains revealed known antibiotics, as well as several new angucyclinone polyketides.

The Streptomyces isolate ICBB8309 was cultured at $28^{\circ} \mathrm{C}$ for 10 days in yeast, malt, and glucose (YMG) medium. The yellow crude extract obtained from the culture broth was separated on silica gel and Sephadex LH20, and final purification was done by preparative HPLC which delivered the known antibiotics actiphenol [2] and naramycin B [3] and the previously described angucyclinones (-)-6-deoxy-8- $O$-methylrabelomycin (1a) [4], 8-O-methylrabelomycin (1b) [4], SM-196B (1c) [5], and tetrangulol methyl ether (2a) [6]. These known compounds were identified by substructure, MS and NMR data searches in the natural products database, Antibase [7]. In addition, the new angucyclinones 7-deoxo-6-deoxy-7hydroxy-8- $O$-methylrabelomycin (1d) and angucyclinone $\mathrm{C}$ (3) were discovered (Fig. 1), as well as 4-methoxy-3Hisobenzofuran-1-one [8], which is described here for the first time from a natural source. In the same manner, the crude extract of the isolate ICBB8415 grown in YMG medium delivered in addition to the known metabolites found in ICBB8309, the polyene sabaramycin A [9]

P. J. Proteau (Corresponding author), S. Fotso, T. Mahmud, T. M. Zabriskie: Department of Pharmaceutical Sciences, College of Pharmacy, 203 Pharmacy Building, Corvallis, Oregon 973313507, USA

D. A. Santosa, Sulastri: Indonesian Center for Biodiversity and Biotechnology, ICBB-Complex, J1. Cilubang Nagrak No. 62, Situgede, Bogor 16115, Indonesia

D. A. Santosa: Department of Soil and Land Resources, Faculty of Agriculture, Bogor Agricultural University, Jl. Meranti, Kampus IPB Darmaga, Bogor 16680, Indonesia 

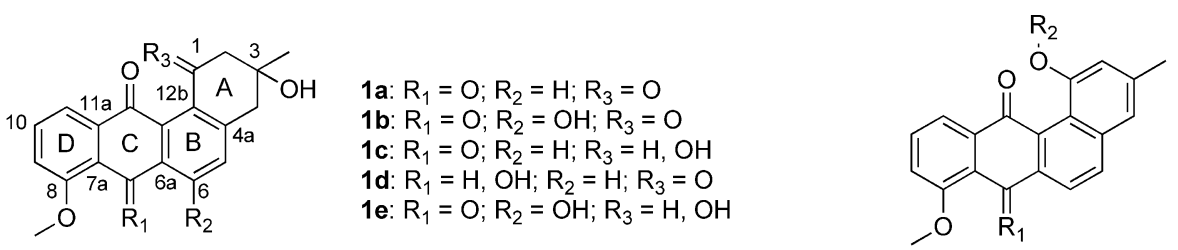

2a: $R_{1}=O ; R_{2}=H$

2b: $\mathrm{R}_{1}=\mathrm{H}, \mathrm{OH} ; \mathrm{R}_{2}=$ Rhamnosyl
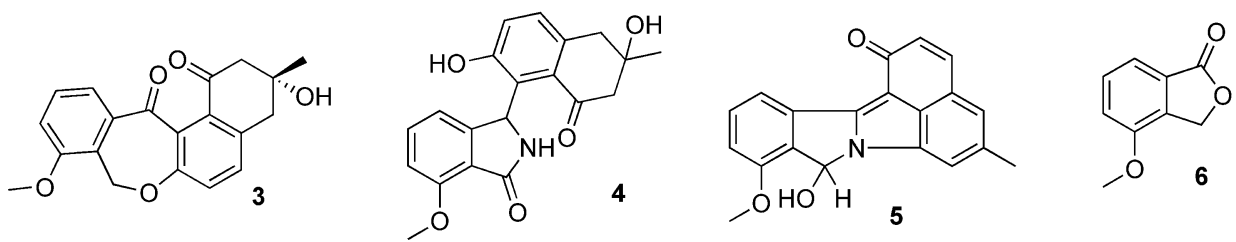

Fig. 1 Structures of angucyclinones and a related compound from Streptomyces strains ICBB8309 and ICBB8415.

$\mathbf{1 a}=(-)$-6-deoxy-8-O-methylrabelomycin; $\quad \mathbf{1 b}=8-O-$ methylrabelomycin; $\quad \mathbf{1 c}=\mathrm{SM}-196 \mathrm{~B} ; \quad \mathbf{1 d}=7-$ deoxo-6-deoxy-7-hydroxy-8-O-
thylrabelomycin; $\mathbf{1 e}=1$-deoxo-1-hydroxy-8-O-methylrabelomycin; $\mathbf{2 a}=$ tetrangulol methyl ether; $\mathbf{2} \mathbf{b}=7$-deoxo-7-hydroxy-1-O- $\alpha$-rhamnosymethylrabelomycin; $\mathbf{1 e}=1$-deoxo-1-hydroxy-8-O-methylrabelomycin; $\mathbf{2} \mathbf{a}=$ tetrangulol methyl ether; $\mathbf{2} \mathbf{b}=7$-deoxo-7-hydrc
8-O-methyltetrangulol; $\mathbf{3}=$ angucyclinone $\mathrm{C} ; \mathbf{4}=$ limamycin $\mathrm{A} ; \mathbf{5}=$ limamycin $\mathrm{B} ; \mathbf{6}=4$-methoxy-3H-isobenzofuran-1-one.

and the novel metabolites 1-deoxo-1-hydroxy-8-Omethylrabelomycin (1e), 7-deoxo-7-hydroxy-1-O- $\alpha$ rhamnosyl-8-O-methyltetrangulol (2b), limamycin A (4), and limamycin B (5) (Fig. 1).

\section{Results and Discussion}

Compound 1d was obtained as a yellow oil. The ${ }^{1} \mathrm{H}$ - and ${ }^{13} \mathrm{C}$-NMR spectra exhibited 16 proton and 20 carbon resonances, including two carbonyls at $\delta=198.5$ and 186.4 instead of three as in the spectrum of 1a. The HSQC spectrum indicated the presence of one $C$ - and one $O$ methyl, two methylenes, one $O$-substituted methine, and five aromatic methines. The remaining ${ }^{13} \mathrm{C}$-NMR resonances included one quaternary $s p^{3}$, two carbonyls and seven quaternary $s p^{2}$ carbon atoms. The HREI-MS for the molecular ion at $m / z 338.1143$ along with the NMR data corresponded to a molecular formula of $\mathrm{C}_{20} \mathrm{H}_{18} \mathrm{O}_{5}$ suggesting the presence of two exchangeable protons. The proton NMR spectrum of $\mathbf{1 d}$ is very similar with that of $\mathbf{1 a}$ with a 1,2,3-trisubstituted aromatic system, isolated orthocoupled aromatic protons, and a methoxy group at $\delta=3.99$ which exhibited a correlation in the HMBC spectrum to the carbon at $\delta=157.3$ (C-8) (Fig. 2). Two methylene groups, one as a coupled pair of doublets at $\delta=3.04$ and 2.76 $(J=16.0 \mathrm{~Hz})$ and one as a singlet at $\delta=3.04$, along with a methyl singlet at $\delta=1.36$ were visible and were correlated to the quaternary carbon at $\mathrm{C}-3(\delta=70.5)$ in the HMBC spectrum. Furthermore, a methine singlet appears at $\delta=5.88$ that was absent in 1a suggesting the reduction of one carbonyl group in 1a. This methine correlates to the carbon at $\delta=61.6$ in the HSQC spectrum. The position of the new secondary alcohol was defined by the correlation of $\mathrm{H}-6$ to the methine carbon at $\delta=61.6$ indicating that the carbonyl at $\mathrm{C}-7$ in $\mathbf{1 a}$ was reduced in $\mathbf{1 d}$ providing the new angucyclinone, 7-deoxo-6-deoxy-7-hydroxy-8-Omethylrabelomycin (1d). Compound 1d, although chemically stable, was readily oxidized to 6-deoxy-8-Omethylrabelomycin (1a) using pyridinium chlorochromate (PCC).

Compound 1e was obtained as a yellow oil from a preparative HPLC separation. The ${ }^{1} \mathrm{H}-\mathrm{NMR}$ spectrum is very similar to that of $\mathbf{1 b}$, with the major difference between the spectra being the presence in $\mathbf{1 e}$ of a broad apparent quartet $(\delta=5.40)$ and doublet $(\delta=4.92$; exchangeable proton) integrating for one proton each suggesting that one of the carbonyls in $\mathbf{1 b}$ has been reduced. The ${ }^{1} \mathrm{H},{ }^{1} \mathrm{H}-\mathrm{COSY}$ spectrum showed a coupling between the methine at $\delta=5.40$ and the doublet of doublet methylene protons (H-2) indicating that the C-1 carbonyl has been reduced. The carbon spectrum supported this conclusion on the basis of only two carbonyl groups at $\delta=188.6$ and 187.3 in 1e and the presence of an additional methine carbon at $\delta=65.0$. The reduction of the carbonyl at $\mathrm{C}-1$ was confirmed by the HMBC correlation of the $\mathrm{H}-2$ protons to C-1 at $\delta=65.0$ (Fig. 2). The name 1-deoxo-1hydroxy-8-O-methylrabelomycin is proposed for $\mathbf{1 e}$. Although the compound was found to be stable in solution, it appears to be readily oxidized to $\mathbf{1 b}$ during measurement of the mass spectrum.

High resolution MS data of the yellow compound $\mathbf{2 b}$ suggested a molecular formula of $\mathrm{C}_{26} \mathrm{H}_{26} \mathrm{O}_{8}$. The ${ }^{1} \mathrm{H}-\mathrm{NMR}$ spectrum was similar to that of $\mathbf{2 a}$, but there was a new 

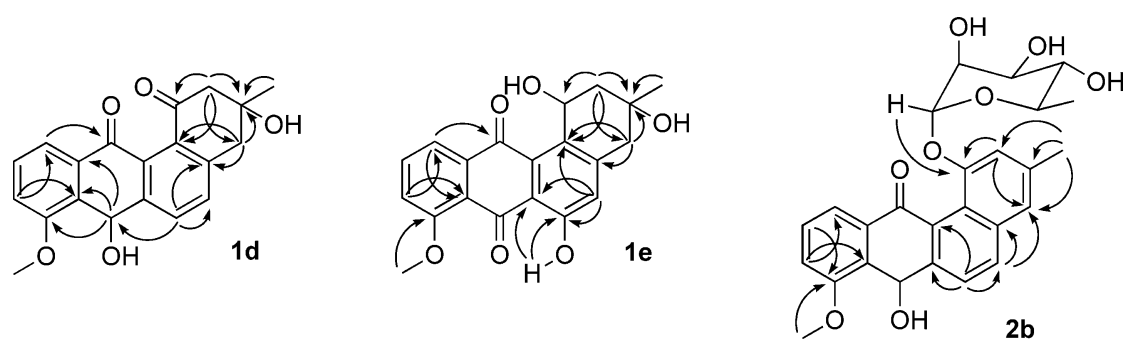

Fig. 2 Selected HMBC correlations for compounds $\mathbf{1 d}$, $\mathbf{1 e}$, and $\mathbf{2 b}$.
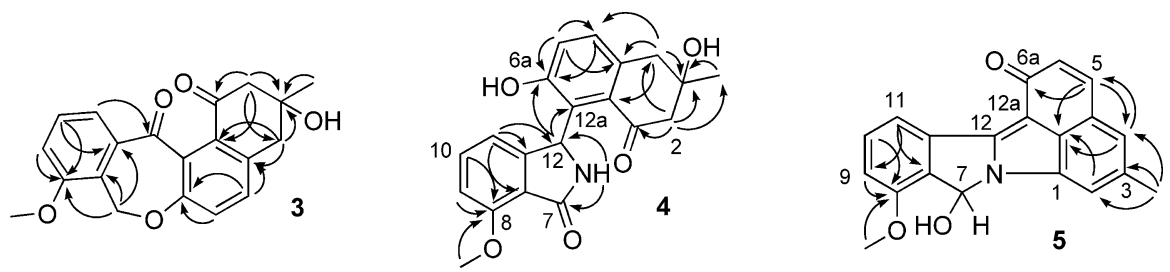

Fig. 3 Selected HMBC correlations for compounds 3, 4, and $\mathbf{5}$ (the numbering for compounds $\mathbf{4}$ and $\mathbf{5}$ retains the numbering from the putative angucyclinone precursors).

singlet at $\delta=7.00$, five new coupled protons ranging from $\delta=5.78$ to 3.65 , and a methyl doublet at $\delta=1.33$. Coupling data in the ${ }^{1} \mathrm{H},{ }^{1} \mathrm{H}-\mathrm{COSY}$ spectrum indicated the presence of a sugar residue in $\mathbf{2 b}$ and the anomeric proton at $\delta=5.78$ had a small coupling $(J=1.9 \mathrm{~Hz})$ which indicated an $\alpha$ linkage to the aglycone. The sugar was identified as a rhamnose on the basis of the coupling constants and comparison with literature data $[10,11]$.

The ${ }^{13} \mathrm{C}$-NMR spectrum showed 26 carbons, which includes the six carbons for the rhamnose, but revealed only one downfield signal $(\delta=185.0)$ instead of two as in 2a, suggesting a reduction of one carbonyl, which was supported by the presence of a $s p^{3}$ methine carbon at $\delta=66.9$. A ${ }^{1} \mathrm{H},{ }^{1} \mathrm{H}-\mathrm{COSY}$ correlation between a broad singlet at $\delta=7.00$ and H- 6 suggests that the C-7 carbonyl was reduced. The position of the $O$-sugar was determined from the interpretation of the HMBC spectrum, which exhibited a small cross peak of the anomeric proton $(\delta=5.78)$ to the $\mathrm{C}-1$ carbon at $\delta=156.7$ (Fig. 2). The name 7-deoxo-7-hydroxy-1-O- $\alpha$-rhamnosyl-8- $O$ methyltetrangulol is proposed for compound $\mathbf{2} \mathbf{b}$.

Compound $\mathbf{3}$ was obtained as a yellow oil. EIMS and HRCI-MS presented the molecular formula for $\mathbf{3}$ as $\mathrm{C}_{20} \mathrm{H}_{18} \mathrm{O}_{5}$, which was supported by the NMR data. The ${ }^{1} \mathrm{H}-$ NMR spectrum shows similarity with those of $\mathbf{1 a}$ and $\mathbf{1 b}$ with the three consecutive aromatic protons, a methoxy resonance, the methyl singlet and two $\mathrm{AB}$ resonances attributed to two methylene groups at $\delta 3.08$ and $\delta 2.62$. In addition, the ${ }^{1} \mathrm{H}$-NMR spectrum indicates a new two-proton singlet at $\delta 5.08$, while the methine singlet which appears in 1d at $\delta 5.58(\mathrm{H}-7)$ is absent in 3. The ${ }^{13} \mathrm{C}-\mathrm{NMR}$ spectrum indicated 20 carbon resonances including two carbonyl carbons as in 1d and 1e. The DEPT experiment established the multiplicities of the carbon resonances as five $s p^{2}$ methines, one methoxy, one methyl, and three methylene carbons, and the remaining eight carbon signals represent quaternary carbons (seven $s p^{2}$ and one $s p^{3}$ ). The major difference between the ${ }^{13} \mathrm{C}$ spectra of $\mathbf{1 d}$ and $\mathbf{3}$ is the replacement of the methine at $\delta 61.6$ in $\mathbf{1 d}$ by an oxygenbearing methylene at $\delta 55.0$ in compound $\mathbf{3}$.

Interpretation of the HMBC spectrum indicated that both methylene protons at $\delta=3.08$ and 2.62 had correlations to the carbon at $\delta=70.9$ (C-3), the quaternary carbon at $\delta=130.5$ (C-12b) and the methyl carbon $(\delta=27.8)$. In addition, the methyl proton and the $\mathrm{H}-4$ protons correlated to the carbon at $\delta=133.6$ (C-4a) and important couplings were observed between the proton at $\delta=7.31(\mathrm{H}-5)$ and the methylene carbon at $\delta=42.0(\mathrm{C}-4)$ and the quaternary carbon at $\delta=153.1$ (C-6a), providing the $\mathrm{A}$ and $\mathrm{B}$ rings seen in compounds 1a and 1d (Fig. 3). A key difference, however, is the ${ }^{13} \mathrm{C}-\mathrm{NMR}$ shift of C-6a $(\delta=153.1)$, which indicates $\mathrm{C}-6 \mathrm{a}$ is connected to an oxygen, rather than a carbon.

The second structure element of $\mathbf{3}$ was determined based on the similarity of the aromatic regions of the NMR spectra with those of $\mathbf{1 a}$ and $\mathbf{1 b}$ (a 1,2,3-trisubstituted benzene ring bearing a methoxy group). The remaining carbonyl group at $\delta=201.1$ and the methylene at $\delta=55.0$ 
are required to connect the substructures. The important HMBC correlation between the protons at $\delta 5.08$ and the carbon at $\delta=158.2(\mathrm{C}-8)$, the ${ }^{13} \mathrm{C}$ chemical shift of C-6a, as well as the lack of a correlation between H-6 and the carbonyl at $\delta=201.1$, support structure 3. The structure represented by $\mathbf{3}$ was previously reported as angucyclinone $\mathrm{C}$ in a review by Rohr et al. [12], but no data was available to support the structure. Therefore, we report these data here for the first time. Angucyclinone C (3) is a ringexpanded angucyclinone that has the same tetracyclic ring structure as emycin D, an angucyclinone from the mutant strain Streptomyces cellulosae ssp. griseoincarnatus 1114-2 [13]. It may arise from the oxidative cleavage of 6-deoxy-8$O$-methylrabelomycin (1a) followed by enzymatic reduction at C-7. A similar mechanistic hypothesis has been previously described by Rohr et al. [13] for the formation of emycin D through an enzymatic BaeyerVilliger oxidation of ochromycinone. Because (-)-6deoxy-8- $O$-methylrabelomycin (1a) has the $R$ configuration at C-3 [14], and 3 likely derives from 1a, the $R$ configuration is also proposed for $\mathrm{C}-3$ of $\mathbf{3}$.

Compound 4 was isolated as a white powder. The molecular formula, $\mathrm{C}_{20} \mathrm{H}_{19} \mathrm{NO}_{5}$, was suggested from the HRESI-MS spectrum. The ${ }^{13} \mathrm{C}-\mathrm{NMR}$ spectrum included carbons at $\delta=201.4$ and 169.7, which indicated the presence of a ketone and an amide, acid or ester, respectively. The presence of two methylene groups as $\mathrm{AB}$ quartets at $\delta=2.97$ and 2.78 and the methyl singlet $(\delta=1.27)$ in the ${ }^{1} \mathrm{H}-\mathrm{NMR}$ spectrum reflected a similar aliphatic region to that observed in $\mathbf{3}$, suggesting an identical A-ring. The $s p^{2}$ region of 4 indicated two exchangeable protons at $\delta=9.17$ and 8.16 in addition to four doublets and a triplet, which represent the 1,2,3 trisubstituted aromatic system and the isolated orthocoupled protons that are found in compounds $1 \mathbf{1 a}, \mathbf{1 c}, \mathbf{1 d}$, 2a, 2b and 3. Finally, a broad methine singlet appeared at $\delta=6.84$.

Interpretation of the HMBC spectrum confirmed an Aring identical to that in $\mathbf{3}$, as well as establishing that it was fused to an aromatic ring bearing ortho-coupled protons. Important correlations included the proton at $\delta=7.08(\mathrm{H}-5)$ to the carbons at $\delta=155.9$ (C-6a), 133.0 (C-12b), and $124.5(\mathrm{C}-12 \mathrm{a})$, the proton at $\delta=6.77(\mathrm{H}-6)$ to the carbons at $\delta=133.7(\mathrm{C}-4 \mathrm{a})$ and $124.5(\mathrm{C}-12 \mathrm{a})$, and the protons at $\delta=2.97(\mathrm{H}-4)$ to the carbons at $\delta=133.7$ and $130.4(\mathrm{C}-5)$ (Fig. 3). The HMBC correlations provided A and $\mathrm{B}$ rings nearly identical to those seen in $\mathbf{3}$, including the oxygenbearing C-6a.

The second part of the structure contained the methoxy substituted aromatic system (D ring), a carbonyl at $\delta=169.7$, a methine carbon at $\delta=52.8$, and an exchangeable proton at $\delta 8.16$. The nitrogen indicated by the MS data also must be included in this substructure. The HMBC correlations of the triplet at $\delta=7.35(\mathrm{H}-10)$ and the doublet at $\delta=6.67(\mathrm{H}-11)$ to the methine carbon at $\delta=52.8$ (C-12) place the methine adjacent to H-11. The HMBC spectrum also displayed correlations of the proton at $\delta=8.16$ to both the carbonyl at $\delta=169.7$ and to the methine at $\delta=52.8$. Because the two oxygens available for this substructure have already been incorporated (methoxy, carbonyl), the exchangeable proton must be connected to the lone nitrogen. This positions the nitrogen between the carbonyl and the methine at $\delta=52.8$ (C-12), whose chemical shift is consistent with a bond to nitrogen. Finally, an HMBC correlation from $\delta=6.91(\mathrm{H}-9)$ to the carbon at $\delta=169.7$ (C-7) places the carbonyl adjacent to the methoxy group. The dihydroisoindolone substructure is supported by comparison of the ${ }^{13} \mathrm{C}$-NMR shifts with those for the model compound 2,3-dihydro-7-methoxy-1 $H$-isoindol-1-one [15].

Weak HMBC correlations from H-12 $(\delta=6.84)$ to C-12a $(\delta=124.5)$ and C-6a $(\delta=155.9)$ connect the two substructures, providing structure 4 , which has been named limamycin A. It is likely derived from a rearrangement of (-)-6-deoxy-8-O-methylrabelomycin (1a), but the origin of the nitrogen is unknown. The structure of limamycin A has the same carbon skeleton as emycin E isolated from Streptomyces cellulosae ssp. griseoincarnatus 1114-2 [13].

Compound $\mathbf{5}$ was obtained as a yellow oil from preparative HPLC. The proton NMR spectrum of $\mathbf{5}$ shows some similarities to that of $\mathbf{2 b}$ with the methoxy group at $\delta=3.95$, the aromatic methyl singlet at $\delta=2.55$ and a downfield methine proton at $\delta=6.88$. The aromatic protons were sorted into three spin systems from the ${ }^{1} \mathrm{H},{ }^{1} \mathrm{H}-\mathrm{COSY}$ spectrum: a 1,2,3-trisubstituted aromatic system, two doublets of adjacent protons and two aromatic protons in a meta relationship. The carbon NMR spectrum indicated 20 carbon signals including only one carbonyl at $\delta=179.6$, one $s p^{2}$ oxygenated carbon at $\delta=155.9$, and a methine carbon at $\delta=81.4$ which is downfield compared to the C-7 methine of the reduced angucyclinones $\mathbf{1 d}$ and $\mathbf{2 b}$, suggesting that this methine is in a different environment. The molecular weight of 317 Daltons was deduced from the (+)-ESI MS and the high resolution measurement of that peak indicated the formula $\mathrm{C}_{20} \mathrm{H}_{15} \mathrm{NO}_{3}$, which was consistent with the NMR data. This formula requires 14 unsaturations, which is one or two unsaturations higher than angucyclinones $\mathbf{1 a} \sim \mathbf{e}$. Interpretation of the HMBC spectrum indicated correlations of the aromatic methyl to the carbons at $\delta=133.8(\mathrm{C}-3), 123.5(\mathrm{C}-4)$ and $113.9(\mathrm{C}-2)$. In addition, the proton at $\delta=7.79(\mathrm{H}-5)$ displayed cross peaks to the carbons at $\delta=123.5(\mathrm{C}-4), 128.2(\mathrm{C}-12 \mathrm{~b})$, and to the carbonyl at $\delta=179.6$, and the meta coupled protons 
H-2 and H-4 had correlations to $\delta=128.2$ (C-12b), which helped to construct a methyl-substituted naphthalenone substructure. An additional substructure was confirmed as a 1,2,3-trisubstituted aromatic system with a methoxy substitutent due to the correlations of the H-10, H-9, and methoxy protons to the carbon at $\delta=155.9(\mathrm{C}-8)$.

A search in AntiBase with these fragments yielded HKI 0231A and B, which were isolated from Streptomyces sp. HKI 0231 [16]. These compounds, however, possess three or two methoxy groups, respectively, instead of one as in $\mathbf{5}$. Compound $\mathbf{5}$ was determined to be the $O$-desmethyl analog of HKI 0231B and has been named limamycin B. Limamycin B may be the biosynthetic precursor to HKI 0231B, although it should be noted that $\mathbf{5}$ is optically active, whereas HKI 0231B is not.

Limamycin B (5) was previously reported as an intermediate in the synthesis of HKI 0231B [17], but this is the first report of $\mathbf{5}$ from a natural source. Biosynthetically it may be derived from 4 by cyclization followed by dehydration and rearrangement, along with reduction at $\mathrm{C}$ 7 of 4 (which may occur prior to cyclization).

Compound $\mathbf{6}$ was isolated as a white powder. The proton NMR spectrum exhibited an apparent triplet at $\delta=7.57$ $(J=7.7 \mathrm{~Hz})$ and two doublets at $\delta=7.45(J=7.7 \mathrm{~Hz})$ and $7.32(J=7.7 \mathrm{~Hz})$ which were attributed to a $1,2,3-$ trisubstituted aromatic system. The aliphatic region indicated only two singlets, due to methylene and methoxy protons at $\delta=5.34$ and 3.96, respectively. Based on the $\mathrm{MW}=165$ and the presence of a carbonyl carbon in the ${ }^{13} \mathrm{C}$ NMR spectrum, the structure must contain another ring in addition to the aromatic ring. Combining the partial structures led to the two known phthalides, 4-methoxy-3Hisobenzofuran-1-one and 7-methoxy-3H-isobenzofuran-1one. Comparison of ${ }^{1} \mathrm{H}-\mathrm{NMR}$ data in $\mathrm{CDCl}_{3}$ with values in the literature suggested that $\mathbf{6}$ was 4-methoxy-3Hisobenzofuran-1-one [8]. An HMBC spectrum which showed correlations from $\mathrm{H}-3$ to $\mathrm{C}-1, \mathrm{C}-3 \mathrm{a}, \mathrm{C}-4$, and C-6a confirmed this assignment. Although compound $\mathbf{6}$ has been prepared synthetically $[8,18]$, this is the first report as a natural product. The structural similarity of 6 to the D-rings of the angucyclinones isolated from ICBB 8309 suggests that this compound arises from oxidative cleavage of one of them, such as angucyclinone $\mathrm{C}(\mathbf{3})$.

\section{Biological Activities}

Although the new compounds did not display the dominant antibiotic activity of these strains, which is attributed to actiphenol, naramycin B, and sabaramycin, they were all tested for antibiotic activity. Compounds 1d, 3, 4 and $\mathbf{5}$ were tested at a concentration of $50 \mu \mathrm{g} /$ disk, while compounds $\mathbf{1 e}$ and $\mathbf{2 b}$ were tested at 60 and $45 \mu \mathrm{g} / \mathrm{disk}$, respectively, against Bacillus subtilis, Staphylococcus aureus, Escherichia coli, Pseudomonas aeruginosa, Mycobacterium smegmatis, Mucor miehei and Candida albicans in disk diffusion assays. Compound 1d exhibited weak activity against $S$. aureus $(8.0 \mathrm{~mm}), P$. aeruginosa $(11 \mathrm{~mm})$ and Mucor miehei $(8.0 \mathrm{~mm})$; compound 1e had weak activity against $S$. aureus $(10 \mathrm{~mm})$ and Mycobacterium smegmatis $(8.0 \mathrm{~mm})$, and compound $\mathbf{3}$ inhibited S. aureus $(8.0 \mathrm{~mm})$ and Mucor miehei $(8.0 \mathrm{~mm})$. For comparison, tetramycin at $50 \mu \mathrm{g} /$ disk as a positive control against Mucor miehei provided a $17 \mathrm{~mm}$ inhibition zone. No antibiotic activity was observed for the other metabolites. Compounds $\mathbf{1 d}$ and $\mathbf{3}$ also exhibited moderate antiproliferative activity against PC3-cells (androgen independent prostate cancer cells) as determined by MTT assays [19]. They were tested at two concentrations (10 and $100 \mu \mathrm{M})$ and cell viability was measured at 24 hours and 48 hours. Neither compound significantly affected cell viability at 24 hours at either concentration, but both compounds resulted in a cell viability of $50 \%$ at 48 hours at each concentration.

\section{Experimental}

\section{General}

NMR spectra were measured on a Bruker Unity $300 \mathrm{MHz}$ spectrometer. ESI-MS were recorded on a ThermoFinnigan LCQ Advantage system. HRESI mass spectra were recorded on a Waters/Micromass LCT spectrometer. HREIMS and HRCI-MS were measured on a JEOL HMS-600H MS route magnetic sector instrument. IR spectra were recorded on a Nicolet IR100 FT-IR spectrophotometer. UVVIS spectra were recorded on a Beckmann DU 640 B spectrophotometer. Optical rotations were measured on a Jasco P1010 polarimeter (10 and $100 \mathrm{~mm}$ cells were used). Preparative HPLC was performed using an RP C18 column (Phenomenex, RP 100-C18, $5 \mu \mathrm{m}$ ) with the detector set at $254 \mathrm{~nm}$. Flash chromatography was carried out on silica gel (230 400 mesh). Size exclusion chromatography was done on Sephadex LH-20 (Pharmacia).

\section{Identification of the Producing Strains}

Details of the isolation of bacterial strains and general procedures for the $16 \mathrm{~S}$ rDNA analysis were as previously described [1]. The cultures of Streptomyces strains ICBB8309 and ICBB8415 were deposited at the ICBB-CC (Indonesian Center for Biodiversity and Biotechnology Culture Collection of Microorganisms) as $0.5 \mathrm{ml}$ of a $20 \%$ glycerol stock stored at $-20^{\circ} \mathrm{C}$. The $16 \mathrm{~S}$ rRNA gene sequences of Streptomyces strains ICBB8309 (Genbank 
EU490287) and ICBB8415 (Genbank EU490288) were found to be $99.8 \%$ identical over a 1394 bp overlap region. Both were found to have $>99.4 \%$ identity $(\sim 1400 \mathrm{bp}$ overlap) with the $16 \mathrm{~S}$ rRNA of Streptomyces sp. 98-62 (Genbank DQ450946) and >99.2\% identity ( $1400 \mathrm{bp}$ overlap) with the $16 \mathrm{~S}$ rRNA of Streptomyces gelaticus strain NRRL B-2928 (Genbank DQ026636).

\section{Fermentation and Isolation}

The strain Streptomyces sp. ICBB8309 was cultured in 20 1-liter Erlenmeyer flasks each containing $250 \mathrm{ml}$ of $\mathrm{YMG}$ medium at $28^{\circ} \mathrm{C}$ for 10 days: $4.0 \mathrm{~g}$ glucose, $4.0 \mathrm{~g}$ yeast, $10 \mathrm{~g}$ malt and 1-liter tap water. The $\mathrm{pH}$ was adjusted to 7.8 with $2 \mathrm{~N} \mathrm{NaOH}$ before sterilization. The yellow culture broth was filtered over Celite and the mycelial cake was extracted sequentially with EtOAc and $\mathrm{MeOH}$. The aqueous filtrate was passed through Diaion HP-20 resin, which was then washed with deionized water and the desired compounds were eluted with $\mathrm{MeOH}$. The organic phases from the mycelium and resin extracts were evaporated and the residual water was extracted with EtOAc. Because both extracts contained the same constituents based on TLC, they were mixed and concentrated to a dark yellow oil. The extract was chromatographed on silica gel with a $\mathrm{CH}_{2} \mathrm{Cl}_{2} / \mathrm{MeOH}$ gradient and nine fractions were obtained. Fraction 1 contained only fatty acids and was not further separated. Preparative TLC (PTLC; $\mathrm{CH}_{2} \mathrm{Cl}_{2}$ ) of fraction 2 followed by preparative HPLC with a gradient from $20 \%$ $\mathrm{MeOH} / \mathrm{H}_{2} \mathrm{O}$ to $100 \% \mathrm{MeOH}$ delivered tetrangulol methyl ether (2a, $5.0 \mathrm{mg})$ and 4-methoxy-3H-isobenzofuran-1-one $(6,3.0 \mathrm{mg})$. Trituration of fraction 3 in $\mathrm{MeOH}$ delivered the colorless solid, actiphenol $(70 \mathrm{mg})$. The purification of fraction 4 on Sephadex LH-20 $\left(50 \% \mathrm{MeOH} / \mathrm{CH}_{2} \mathrm{Cl}_{2}\right)$ gave three sub-fractions, 4I, 4II and 4III. Sub-fraction 4I contained naramycin B $(100 \mathrm{mg})$. PTLC of fraction $4 \mathrm{II}$ in $6.0 \% \mathrm{MeOH} / \mathrm{CH}_{2} \mathrm{Cl}_{2}$ and Sephadex LH-20 (MeOH) chromatography delivered 6-deoxy-8-O-methylrabelomycin (1a, $3.0 \mathrm{mg}$ ) and 8-O-methylrabelomycin (1b, $4.0 \mathrm{mg}$ ). Preparative HPLC of fraction 4III using a gradient from $20 \% \mathrm{MeOH} / \mathrm{H}_{2} \mathrm{O}$ to $100 \% \mathrm{MeOH}$ yielded $\mathrm{SM}-196-\mathrm{B}$ (1c, $7.0 \mathrm{mg}$ ). Fraction 6 was chromatographed on Sephadex LH$20(\mathrm{MeOH})$, resulting in two sub-fractions. The purification of 6I on HPLC gave 7-deoxo-6-deoxy-7-hydroxy-8-Omethylrabelomycin (1d, $8.0 \mathrm{mg})$. The purification of fraction 8 on Sephadex LH-20 $(\mathrm{MeOH})$ and preparative HPLC delivered angucyclinone $\mathrm{C}(\mathbf{3}, 500 \mathrm{mg})$ as a major metabolite. It is important to note that during all the chromatographic separations, the flasks as well as test tubes were covered with aluminum foil to prevent light degradation of the metabolites, which was observed during screening on a 1-liter scale.
The strain ICBB8415 was cultivated on a 5-liter scale in YMG medium for 5 days followed by a standard work up. During all separations the columns were wrapped with foil to avoid photochromism and slow decomposition. The yellow crude extract was dissolved in a mixture of $50 \%$ $\mathrm{MeOH} / \mathrm{CH}_{2} \mathrm{Cl}_{2}$ and a yellow solid powder remained, which was identified as sabaramycin A $(6.0 \mathrm{mg})$. The soluble material was separated over silica gel using a $\mathrm{MeOH} / \mathrm{CH}_{2} \mathrm{Cl}_{2}$ gradient to give five fractions. Purification of fraction 2 delivered naramycin $\mathrm{B}(25 \mathrm{mg})$, 8-Omethylrabelomycin (1b, $2.0 \mathrm{mg}), 1$-deoxo-1-hydroxy-8-Omethylrabelomycin (1e, $4.0 \mathrm{mg})$ and limamycin B (5, $3.0 \mathrm{mg}$ ). Trituration of fraction 3 with $\mathrm{MeOH}$ delivered the solid actiphenol and purification of the mother liquor yielded angucyclinone C (3, $15 \mathrm{mg})$. Fraction 4 was purified on HPLC using a gradient from $20 \% \mathrm{MeOH} / \mathrm{H}_{2} \mathrm{O}$ to $100 \% \mathrm{MeOH}$ to yield 6-deoxy-8-O-methyl rabelomycin (1a, $16 \mathrm{mg}$ ), 7-deoxo-7-hydroxy-1- $O$ - $\alpha$-rhamnosyl-8- $O$ methyltetrangulol (2b, $4.0 \mathrm{mg})$ and limamycin A (4, $15 \mathrm{mg})$.

7-Deoxo-6-deoxy-7-hydroxy-8-O-methylrabelomycin (1d) Yellow oil; $[\alpha]_{\mathrm{D}}^{23}=+53^{\circ}(c$ 0.078, MeOH); UV $(\mathrm{MeOH}): \lambda$ $(\log \varepsilon)=331$ (3.71), 278 (4.10), 290 (4.09), 236 (4.50) nm; IR (neat): $v=3419,2959,2909,2847,1687,1658,1590$, $1466,1302,1259,1120,1068,1021,820,746 \mathrm{~cm}^{-1} ;{ }^{1} \mathrm{H}-$ NMR $\left(300 \mathrm{MHz}, \mathrm{MeOH}-d_{4}\right): \delta=7.70(\mathrm{~d}, J=8.0 \mathrm{~Hz}, 1 \mathrm{H}$, H-5), $7.56 \sim 7.49$ (m, 2H, H-10, H-11), 7.42 (d, $J=8.0 \mathrm{~Hz}$, 1H, H-6), 7.27 (dd, J=7.9, $1.4 \mathrm{~Hz}, 1 \mathrm{H}, \mathrm{H}-9), 5.88$ (s, 1H, H-7), 3.99 (s, 3H, $\mathrm{OCH}_{3}$ ), 3.04 (d, J=16.0 Hz, 1H, H-2a), 3.04 (s, 2H, H-4), 2.76 (d, $J=16.0 \mathrm{~Hz}, 1 \mathrm{H}, \mathrm{H}-2 \mathrm{~b}), 1.36$ (s, $\left.3 \mathrm{H}, 3-\mathrm{CH}_{3}\right) ;{ }^{13} \mathrm{C}-\mathrm{NMR}\left(75.5 \mathrm{~Hz}, \mathrm{MeOH}-d_{4}\right): \delta=198.5(\mathrm{C}-$ 1), 186.4 (C-12), 157.3 (C-8), 142.6 (C-4a), 142.4 (C-11a), 135.4 (C-12a), 134.6 (C-6a), 134.0 (C-12b), 133.1 (C-5), 132.9 (C-10), 129.6 (C-6), 129.4 (C-7a), 118.0 (C-11), 114.8 (C-9), 70.5 (C-3), $61.6(\mathrm{C}-7), 55.1\left(\mathrm{OCH}_{3}\right), 53.0(\mathrm{C}-$ 2), $43.1(\mathrm{C}-4), 28.5\left(3-\mathrm{CH}_{3}\right)$; EI-MS $(70 \mathrm{eV}) \mathrm{m} / \mathrm{z}(\%)=338$ $\left([\mathrm{M}]^{+}, 100\right), 318,278,188,171,126,84$; HREI-MS: 338.1143 (338.1154 calcd. for $\mathrm{C}_{20} \mathrm{H}_{18} \mathrm{O}_{5}$ ).

1-Deoxo-1-hydroxy-8-O-methylrabelomycin (1e) Yellow oil; $[\alpha]_{\mathrm{D}}^{23}=+6.1^{\circ}(c 0.11, \mathrm{MeOH})$; UV $(\mathrm{MeOH}): \lambda$ $(\log \varepsilon)=416$ (4.33), 251 (4.58), 227 (4.60) nm. IR (neat): $v=3419,2959,2909,2847,1687,1658,1590,1466,1302$, $1259, \quad 1120,1068, \quad 1021,820,746 \mathrm{~cm}^{-1} ;{ }^{1} \mathrm{H}-\mathrm{NMR}$ $\left(300 \mathrm{MHz}, \mathrm{CDCl}_{3}\right): \delta=13.28(\mathrm{~s}, 1 \mathrm{H}, 6-\mathrm{OH}), 7.91(\mathrm{~d}$, $J=8.4 \mathrm{~Hz}, 1 \mathrm{H}, \mathrm{H}-11$ ), 7.76 (d, $J=8.4 \mathrm{~Hz}, 1 \mathrm{H}, \mathrm{H}-10), 7.37$ (d, $J=8.4 \mathrm{~Hz}, 1 \mathrm{H}, \mathrm{H}-9), 7.10$ (s, 1H, H-5), 5.40 (brq, $J=5.5 \mathrm{~Hz}, 1 \mathrm{H}, \mathrm{H}-1), 4.92$ (d, J=4.3 Hz, 1H, 1-OH), 4.09 (s, $3 \mathrm{H}, \mathrm{OCH}_{3}$ ), $3.00(\mathrm{AB}, J=17.0 \mathrm{~Hz}, 2 \mathrm{H}, \mathrm{H}-4), 2.33$ (brdd, $J=14.1,5.9 \mathrm{~Hz}, 1 \mathrm{H}, \mathrm{H}-2 \mathrm{a}$ ), 2.17 (brdd, $J=14.1,5.5 \mathrm{~Hz}, 1 \mathrm{H}$, 
$\mathrm{H}-2 \mathrm{~b}), 1.52$ (s, 3H, 3-CH 3 ); ${ }^{13} \mathrm{C}-\mathrm{NMR}\left(75.5 \mathrm{~Hz}, \mathrm{CDCl}_{3}\right)$ : $\delta=188.6(\mathrm{C}-7), 187.3(\mathrm{C}-12), 161.8(\mathrm{C}-6), 160.3(\mathrm{C}-8)$, 146.3 (C-4a), 136.9 (C-11a), 135.8 (C-10), 133.7 (C-12b), 133.1 (C-12a), 125.9 (C-5), 120.4 (C-11), 120.0 (C-7a), 117.9 (C-9), 117.2 (C-6a), 69.1 (C-3), 65.0 (C-1), 56.7 $\left(\mathrm{OCH}_{3}\right), 45.6(\mathrm{C}-4), 44.2(\mathrm{C}-2), 29.5\left(3-\mathrm{CH}_{3}\right) ; \mathrm{EI}-\mathrm{MS}$ $(70 \mathrm{eV}) \mathrm{m} / \mathrm{z}(\%)=354[\mathrm{M}]^{+}, 336$; HREI-MS: 354.1064 (354.1103 calcd. for $\mathrm{C}_{20} \mathrm{H}_{18} \mathrm{O}_{6}$ ).

7-Deoxo-7-hydroxy-1-O- $\alpha$-rhamnosyl-8- $O$-methyltetrangulol (2b)

Yellow oil; $[\alpha]_{\mathrm{D}}^{20}=-83^{\circ}(c$ 0.01; $\mathrm{MeOH}) ; \mathrm{UV}(\mathrm{MeOH}): \lambda$ $(\log \varepsilon)=380$ (sh), 275 (3.72), 231 (4.03) nm; IR (neat): $v=3342,2968,2941,2837,1768,1674,1583,1492,1458$, 1439, 1304, 1267, 1235, 1209, 1101, 1029, 957, 921, 880, $823 \mathrm{~cm}^{-1} ;{ }^{1} \mathrm{H}-\mathrm{NMR}\left(300 \mathrm{MHz}\right.$, Acetone- $\left.d_{6}\right): \delta=8.13(\mathrm{~d}$, $J=8.6 \mathrm{~Hz}, 1 \mathrm{H}, \mathrm{H}-6), 7.87$ (d, $J=8.6 \mathrm{~Hz}, 1 \mathrm{H}, \mathrm{H}-5), 7.63$ (t, $J=8.0 \mathrm{~Hz}, 1 \mathrm{H}, \mathrm{H}-10), 7.44$ (s, 1H, 2-H), 7.43 (s, 1H, H-4), 7.36 (d, $J=8.0 \mathrm{~Hz}, 1 \mathrm{H}, \mathrm{H}-11), 7.16$ (d, $J=8.0 \mathrm{~Hz}, 1 \mathrm{H}, \mathrm{H}-9)$, 7.00 (s, 1H, H-7), 5.78 (d, J=1.9 Hz, 1H, H-1'), 4.67 (m, $\left.1 \mathrm{H}, \mathrm{H}-2^{\prime}\right), 4.26$ (dd, J=9.0, 3.6 Hz, 1H, H-3'), 3.90 (s, 3H, $\left.\mathrm{OCH}_{3}\right), 3.88$ (m, 1H, H-5'), 3.65 (t, $\left.J=9.0 \mathrm{~Hz}, 1 \mathrm{H}, \mathrm{H}-4^{\prime}\right)$, $2.53\left(\mathrm{~s}, 1 \mathrm{H}, 3-\mathrm{CH}_{3}\right), 1.33\left(\mathrm{~d}, J=6.2 \mathrm{~Hz}, 3 \mathrm{H}, \mathrm{H}-6^{\prime}\right) ;{ }^{13} \mathrm{C}-$ NMR $\left(75.5 \mathrm{~Hz}\right.$, Acetone- $\left.d_{6}\right): \delta=185.0(\mathrm{C}-12), 161.2(\mathrm{C}-8)$, 156.7 (C-1), 147.5 (C-11a), 140.0 (C-12a), 139.9 (C-3), 139.3 (C-6a), 135.3 (C-10), 133.3 (C-4a), 129.7 (C-5), 124.8 (C-6), 123.6 (C-11), 123.2 (C-4), 122.0 (C-7a), 114.4 (C-2), 113.0 (C-9), 108.2 (C-12b), 101.6 (C-1'), 74.2 (C$\left.4^{\prime}\right), 73.7\left(\mathrm{C}-3^{\prime}\right), 72.0\left(\mathrm{C}-2^{\prime}\right), 71.3\left(\mathrm{C}-5^{\prime}\right), 66.9$ (C-7), 56.7 $\left(\mathrm{OCH}_{3}\right), 22.2\left(\mathrm{CH}_{3}-3\right), 18.7\left(\mathrm{C}-6^{\prime}\right)$; ESI-MS $m / z(\%)=467$ $\left([\mathrm{M}+\mathrm{H}]^{+}, 33\right), 489\left([\mathrm{M}+\mathrm{Na}]^{+}, 100\right), 955\left([2 \mathrm{M}+\mathrm{Na}]^{+}\right.$, 95); HRESI-MS: 467.1702 (467.1706 calcd. for $\mathrm{C}_{26} \mathrm{H}_{27} \mathrm{O}_{8}$ ).

\section{Angucyclinone C (3)}

Yellow oil; $[\alpha]_{\mathrm{D}}^{30}=-13^{\circ}$ (c 0.12; MeOH); UV (MeOH): $\lambda$ $(\log \varepsilon)=324$ (3.20), 256 (3.72), 226 (4.12) nm; IR (neat): $v=3342,2968,2941,2837,1768,1674,1583,1492,1458$, $1439,1304,1267,1235,1209,1101,1029,957,921,880$, $823 \mathrm{~cm}^{-1} ;{ }^{1} \mathrm{H}-\mathrm{NMR}\left(300 \mathrm{MHz}, \mathrm{MeOH}-d_{4}\right): \delta=7.31$ (d, $J=8.4 \mathrm{~Hz}, 1 \mathrm{H}, \mathrm{H}-5), 7.25 \sim 7.14$ (m, 3H, 6, 9, H-10), 6.92 (brdd, $J=6.7,1.5 \mathrm{~Hz}, 1 \mathrm{H}, \mathrm{H}-11), 5.08$ (s, 2H, H-7), 3.90 (s, $\left.3 \mathrm{H}, \mathrm{OCH}_{3}\right), 3.08(\mathrm{AB}, J=16.6 \mathrm{~Hz}, 2 \mathrm{H}, \mathrm{H}-4), 2.62(\mathrm{AB}$, $J=16.6 \mathrm{~Hz}, 2 \mathrm{H}, \mathrm{H}-2), 1.35\left(\mathrm{~s}, 3 \mathrm{H}, 3-\mathrm{CH}_{3}\right) ;{ }^{13} \mathrm{C}-\mathrm{NMR}$ $\left(75.5 \mathrm{~Hz}, \mathrm{MeOH}-d_{4}\right): \delta=201.1(\mathrm{C}-12), 197.8(\mathrm{C}-1), 158.2$ (C-8), 153.1 (C-6a), 139.1 (C-11a), 133.6 (C-4a), 131.4 (C5), 130.5 (C-12b), 129.1 (C-7a), 128.1 (C-10), 127.6 (C12a), 122.7 (C-6), 121.7 (C-11), 114.7 (C-9), 70.9 (C-3), $55.3\left(\mathrm{OCH}_{3}\right), 55.0(\mathrm{C}-7), 51.4(\mathrm{C}-2), 42.0(\mathrm{C}-4), 27.8$ (3$\left.\mathrm{CH}_{3}\right)$; EI-MS $(70 \mathrm{eV}) \mathrm{m} / \mathrm{z}(\%)=338\left([\mathrm{M}]^{+}, 28\right), 320(100)$, 291 (261), 277 (12), 253 (13), 160 (10); HRCI-MS: 338.1153 (338.1154 calcd. for $\mathrm{C}_{20} \mathrm{H}_{18} \mathrm{O}_{5}$ ).
Limamycin A (4)

White powder; $[\alpha]_{\mathrm{D}}^{20}=+14^{\circ}(c 0.25 ; \mathrm{MeOH})$; UV $(\mathrm{MeOH})$ : $\lambda(\log \varepsilon)=329$ (3.66), 291 (3.80), 258 (3.82), 237 (3.87), 212 (3.87) nm; IR (neat): $v=3342,2968,2941,2837$, $1768,1674,1583,1492,1458,1439,1304,1267,1235$, 1209, 1101, 1029, 957, 921, 880, $823 \mathrm{~cm}^{-1} ;{ }^{1} \mathrm{H}-\mathrm{NMR}$ $\left(300 \mathrm{MHz}, \mathrm{DMSO}-d_{6}\right): \delta 9.17(\mathrm{~s}, 1 \mathrm{H}, 6 \mathrm{a}-\mathrm{OH}), 8.16(\mathrm{~s}, 1 \mathrm{H}$, $\mathrm{NH}), 7.35$ (t, $J=8.0 \mathrm{~Hz}, 1 \mathrm{H}, \mathrm{H}-10), 7.08$ (d, $J=8.2 \mathrm{~Hz}, 1 \mathrm{H}$, H-5), 6.91 (d, J=8.2 Hz, 1H, H-9), 6.84 (brs, 1H, H-12), 6.77 (brd, $J=8.2 \mathrm{~Hz}, 1 \mathrm{H}, \mathrm{H}-6), 6.67$ (d, $J=8.2 \mathrm{~Hz}, 1 \mathrm{H}, \mathrm{H}-$ 11), 4.85 (s, 1H, 3-OH), $3.83\left(\mathrm{~s}, 3 \mathrm{H}, \mathrm{OCH}_{3}\right), 2.97(\mathrm{AB}$, $J=16.3 \mathrm{~Hz}, 2 \mathrm{H}, \mathrm{H}-4), 2.78$ (AB, $J=15.6 \mathrm{~Hz}, 2 \mathrm{H}, \mathrm{H}-5), 1.27$ $\left(\mathrm{s}, 3 \mathrm{H}, 3-\mathrm{CH}_{3}\right) ;{ }^{13} \mathrm{C}-\mathrm{NMR}\left(75.5 \mathrm{MHz}, \mathrm{DMSO}-d_{6}\right): \delta=201.4$ (C-1), 169.7 (C-7), 157.0 (C-8), 155.9 (C-6a), 151.6 (C11a), 133.7 (C-4a), 133.0 (C-12b), 132.9 (C-10), 130.4 (C5), 124.5 (C-12a), 121.4 (C-6), 120.9 (C-7a), 115.0 (C-11), 110.2 (C-9), $70.5(\mathrm{C}-3), 55.8\left(\mathrm{OCH}_{3}\right), 54.9(\mathrm{C}-2), 52.8(\mathrm{C}-$ 12), 44.1 (C-4), $29.9\left(3-\mathrm{CH}_{3}\right)$; ESI-MS $m / z(\%)=354$ $\left([\mathrm{M}+\mathrm{H}]^{+}, \quad 100\right), 729\left([2 \mathrm{M}+\mathrm{Na}]^{+}, 30\right)$; HRESI-MS: 376.1187 (376.1185 calcd. for $\mathrm{C}_{20} \mathrm{H}_{19} \mathrm{NO}_{5} \mathrm{Na}$ ).

\section{Limamycin B (5)}

Yellow oil; $[\alpha]_{\mathrm{D}}^{21}=+84^{\circ}(c 0.01, \mathrm{MeOH}) ; \mathrm{UV}(\mathrm{MeOH}): \lambda$ $(\log \varepsilon)=463$ (3.26), 436 (3.31), 380 (sh), 366 (3.22), 287 (3.31), 215 (3.93) nm; IR (neat): $v=3339,2925,2853$, 1672, 1674, 1586, 1558, 1488, 1457, 1377, 1268, 1080, 1024, 855, $756 \mathrm{~cm}^{-1}$; ${ }^{1} \mathrm{H}-\mathrm{NMR}\left(300 \mathrm{MHz}, \mathrm{DMSO}-d_{6}\right)$ : $\delta=8.00(\mathrm{~d}, J=7.9 \mathrm{~Hz}, 1 \mathrm{H}, \mathrm{H}-11), 7.79(\mathrm{~d}, J=9.6 \mathrm{~Hz}, 1 \mathrm{H}$, H-5), 7.64 (t, J=7.9 Hz, 1H, H-10), 7.61 (s, 1H, H-2), 7.45 (d, $J=9.1 \mathrm{~Hz}, 1 \mathrm{H}, 7-\mathrm{OH}), 7.45$ (s, 1H, H-4), 7.26 (d, $J=7.9 \mathrm{~Hz}, 1 \mathrm{H}, \mathrm{H}-9), 6.88$ (d, $J=9.1 \mathrm{~Hz}, 1 \mathrm{H}, \mathrm{H}-7), 6.57$ (d, $J=9.6 \mathrm{~Hz}, 1 \mathrm{H}, \mathrm{H}-6), 3.95\left(\mathrm{~s}, 3 \mathrm{H}, \mathrm{OCH}_{3}\right), 2.55\left(\mathrm{~s}, 3 \mathrm{H}, \mathrm{CH}_{3}\right)$; ${ }^{13} \mathrm{C}-\mathrm{NMR}$ (DMSO- $\left.d_{6}, 75.5 \mathrm{MHz}\right): \delta=179.6(\mathrm{C}-6 \mathrm{a}), 155.9$ (C-8), 147.5 (C-12), 137.5 (C-5), 133.8 (C-3), 132.6 (C7a), 132.2 (C-10), 132.0 (C-6), 131.1 (C-1), 130.5 (C-11a), 128.2 (C-12b), 123.6 (C-12a), 123.5 (C-4), 116.2 (C-11), 114.3 (C-9), 113.9 (C-2), 108.0 (C-4a), 81.4 (C-7), 55.7 $\left(\mathrm{OCH}_{3}\right), 21.7\left(3-\mathrm{CH}_{3}\right)$ (the ${ }^{13} \mathrm{C}-\mathrm{NMR}$ shifts all differ by $\sim 9$ ppm from those previously published [17] due to an inadvertent error in referencing the spectrum; personal communication from A. Scopton and T.R. Kelly); ESI-MS $m / z(\%)=318\left([\mathrm{M}+\mathrm{H}]^{+}, 100\right), 340\left([\mathrm{M}+\mathrm{Na}]^{+}, 100\right), 657$ $\left([2 \mathrm{M}+\mathrm{Na}]^{+}, 37\right)$; HREI-MS: 317.1047 (317.1052 calcd. for $\mathrm{C}_{20} \mathrm{H}_{15} \mathrm{NO}_{3}$ ).

4-Methoxy-3H-isobenzofuran-1-one (6)

White powder; ${ }^{1} \mathrm{H}-\mathrm{NMR}\left(300 \mathrm{MHz}, \mathrm{MeOH}-d_{4}\right): \delta=7.57(\mathrm{t}$, $J=7.7 \mathrm{~Hz}, 1 \mathrm{H}, \mathrm{H}-6), 7.45$ (d, $J=7.7 \mathrm{~Hz}, 1 \mathrm{H}, \mathrm{H}-7), 7.32$ (d, $J=7.7 \mathrm{~Hz}, 1 \mathrm{H}, \mathrm{H}-5), 5.34$ (s, 2H, H-2), 3.96 (s, 3H, $\left.\mathrm{OCH}_{3}\right)$; ${ }^{13} \mathrm{C}-\mathrm{NMR}\left(75.5 \mathrm{MHz}, \mathrm{MeOH}-d_{4}\right): \delta=171.2(\mathrm{C}-1), 154.2$ (C-4), 137.8 (C-3a), 127.4 (C-7a), 116.3 (C-7), 115.1 (C- 
5), $68.2(\mathrm{C}-3), 54.9\left(\mathrm{OCH}_{3}\right) ;$ ESI-MS $m / z \quad(\%)=165$ $\left([\mathrm{M}+\mathrm{H}]^{+}, 100\right), 187\left([\mathrm{M}+\mathrm{Na}]^{+}, 85\right)$.

\section{Biological Assays}

The disk diffusion assay [20] was used to test antibiotic susceptibility. Each test organism was grown at $37^{\circ} \mathrm{C}$ for 24 hours in $3 \mathrm{ml}$ of medium (tryptic soy broth for $S$. aureus; YMG medium for E. coli, P. aeruginosa, and $M y$. smegmatis; potato dextrose broth for M. miehei; and Sabourand broth for C. albicans). The 24 hours cultures $(150 \mu \mathrm{l})$ were mixed with agar medium $(15 \mathrm{ml}$ total) and poured into Petri dishes. $\mathrm{MeOH}$ was used to dissolve each pure compound and $20 \mu \mathrm{l}$ of the compound solution (representing $45 \sim 60 \mu \mathrm{g}$ ) was applied to a $6.0 \mathrm{~mm}$ paper disk (Whatman). The disk was allowed to dry for an hour before it was placed on the plate. The plates were incubated at $37^{\circ} \mathrm{C}$ for bacteria and $30^{\circ} \mathrm{C}$ for fungi and the diameter of the inhibition zone $(\mathrm{mm})$ of each active compound was measured after 24 hours. Disks treated with $20 \mu \mathrm{l} \mathrm{MeOH}$ were used as negative controls. The MTT cell viability assay was performed as previously described [21].

Acknowledgements We thank J. Morré for high resolution mass spectra (supported by a grant from NIEHS-ES00210) and Dr. Emily Ho for conducting the MTT assays. This work was supported by research funds from the College of Pharmacy, Oregon State University.

\section{References}

1. Fotso S, Mahmud T, Zabriskie TM, Santosa DA, Sulastri, Proteau PJ. Angucyclinones from an Indonesian Streptomyces sp. J Nat Prod 71: 61-65 (2008)

2. Highet RJ, Prelog V. Metabolic product of actinomycetes. XVIII. Actiphenol. Helv Chim Acta 42: 1523-1526 (1959)

3. Dieter B, Schedel M, Schmidt RR, Klaus D, Weyland H. Naramycin B, an antibiotic from Streptomyces griseus strain 587 with herbicidal properties - fermentation, isolation, and identification. Z Naturforsch 37C: 1100-1106 (1982)

4. Shigihara Y, Koizumi Y, Tamamura T, Homma Y, Isshiki K, Dobashi K, Naganawa H, Takeuchi T. 6-Deoxy-8-Omethylrabelomycin and 8-O-methylrabelomycin from a Streptomyces species. J Antibiot 41: 1260-1264 (1988)

5. Grabley S, Hammann P, Hutter K, Kluge H, Thiericke R, Wink J, Zeeck A. Secondary metabolites by chemical screening. Part 19. SM 196 A and B, novel biologically active angucyclinones from Streptomyces sp. J Antibiot 44: 670-673 (1991)

6. Maehr H, Liu CM, Liu M, Perrotta A, Smallheer JM, Williams TH, Blount JF. Microbial products. VI Five novel metabolites related to benz $[a]$ anthracene from an unidentified actinomycete designated X-14881. J Antibiot 35: 1627-1631 (1982)
7. Laatsch H. AntiBase, a Natural Products Database for Rapid Structure Determination. Wiley-VCH (2005)

8. Soucy C, Favreau D, Kayser MM. On regioselectivity of metal hydride reactions of 3-substituted phthalic anhydrides. J Org Chem 52: 129-134 (1987)

9. Baradaran-Heravi K. Strukturaufklärung von Sabaramycin A und B: Neue polyenartige makrolactam-Antibiotika Ph.D. Thesis. University of Göttingen (1989)

10. Grond S, Langer H-J, Henne P, Sattler I, Thiericke R, Grabley S, Zähner H, Zeeck A. Secondary Metabolites by Chemical Screening, 39 Acyl $\alpha$-L-Rhamnopyranosides, a Novel Family of Secondary Metabolites from Streptomyces sp.: Isolation and Biosynthesis. Eur J Org Chem 2000: 929 937 (2000)

11. Grond S, Papastavrou I, Zeeck A. Novel alpha-LRhamnopyranosides from a Single Strain of Streptomyces by Supplement-Induced Biosynthetic Steps. Eur J Org Chem 2002: 3237-3242 (2002)

12. Rohr J, Thiericke R. Angucycline Group Antibiotics. Nat Prod Rep 9: 103-137 (1992)

13. Gerlitz M, Udvarnoki G, Rohr J. Biosyntheses of Novel Emycins from the Mutant Strain Streptomyces cellulosae ssp. griseoincarnatus 1114-2. Angew Chem Intl Ed 34: 1617-1621 (1995)

14. Landells JS, Larsen DS, Simpson J. Remote stereochemical control in asymmetric Diels-Alder reactions: synthesis of the angucyclinone antibiotics, (-)-tetrangomycin and MM47755. Tetrahedron Lett 44: 5193-5196 (2003)

15. Lamblin M, Couture A, Deniau E, Grandclaudon P. A concise and efficient synthesis of isoindolin-1-ones. New synthetic approach to the polycyclic framework of vitedoamine A. Tetrahedron 63: 2664-2669 (2007)

16. Kleinwachter P, Schlegel B, Groth I, Hartl A, Grafe U. New inhibitors of 3alpha-hydroxysteriod dehydrogenase, 0231A and 0231B from Streptomyces sp. HKI 0231. J Antibiot 54: 510-512 (2001)

17. Scopton A, Kelly TR. Synthesis of HKI 0231B. J Org Chem 70: 10004-10012 (2005)

18. De Silva SO, Reed JN, Billedeau RJ, Wang X, Norris DJ, Snieckus V. Directed ortho metalation of $N, N$-diethyl benzamides. Methodology and regiospecific synthesis of useful contiguously tri- and tetra-substituted oxygenated aromatics, phthalides, and phthalic anhydrides. Tetrahedron 48: 4863-4878 (1992)

19. Plumb JA, Milroy R, Kaye SB. Effects of the $\mathrm{pH}$ dependence of 3-(4,5-dimethylthiazol-2-yl)-2,5-diphenyltetrazolium bromide-formazan absorption on chemosensitivity determined by a novel tetrazolium-based assay. Cancer Res 49: 4435-4440 (1989)

20. Bauer AW, Kirby WM, Sherris JC, Turck M. Antibiotic susceptibility testing by a standardized single disk method. Am J Clin Pathol 45: 493-496 (1966)

21. Ohtsu H, Ho E, Huang Y-S, Chuang L-T, Bray TM. Conjugated linoleic acid decreases cellular proliferation and inhibits nuclear factor- $\kappa \mathrm{B}$ and activator protein 1 activation in PC3 cancerous prostate epithelial cells. Nutr Res 25: 655-662 (2005) 